Revista Española de Antropología Americana ISSN: 0556-6533

https://doi.org/10.5209/reaa.64966

\title{
Harmony Rules and the Suffix Domain: A Study of Maya Scribal Conventions
}

\author{
Alfonso Lacadena ${ }^{1 \dagger}$ and Søren Wichmann ${ }^{2}$
}

Recibido: 15 de febrero de 2019 / Aceptado: 22 de marzo de 2019

\begin{abstract}
In 2004, Lacadena and Wichmann proposed a set of orthographic rules for the Maya script. The choice of using one of three different patterns of syn- or disharmonic spellings allowed Maya scribes to signal whether word-final syllables contained a short vowel, a long vowel or a glottal stop. In our earlier paper we focused on the lexical evidence for these orthographic «harmony rules». Although it was stated that the rules apply equally well when a suffix is involved and when no suffix is involved, the data relating to the former situation were not discussed in detail. This is the aim of the present paper.
\end{abstract}

Keywords: Maya writing; spelling rules; suffixes; diachrony; theory of writing.

\section{[es] Las reglas de armonía y el dominio de los sufijos: un estudio de las convenciones de los escribas mayas}

Resumen. Lacadena y Wichmann propusimos en 2004 un conjunto de reglas ortográficas para la escritura maya. Escogiendo uno u otro de tres patrones ortográficos de sinarmonía o desarmonía, los escribas mayas podían indicar si la sílaba final de una palabra contenía una vocal corta, una vocal larga o una oclusiva glotal. En aquel artículo nos centramos en la evidencia léxica de estas «reglas de armonía» de la ortografía. Aunque se afirmaba que las reglas se aplican igualmente bien cuando está implicado un sufijo y cuando no lo está, los datos relacionados con la primera de ambas situaciones no se analizaron en detalle. Hacerlo es el objetivo del presente artículo.

Palabras clave: escritura maya; reglas de ortografía; sufijos; diacronía; teoría de la escritura.

Contents. 1. Introduction. 2. The Hypothesis: Expanding Harmony Rules to the Suffix Domain. 3. Internal Evidence for the Hypothesis. 4. Overview. 5. Conclusion. 6. References.

How to cite: Lacadena, Alfonso y Søren Wichmann. 2019. «Harmony Rules and the Suffix Domain: A Study of Maya Scribal Conventions». Revista Española de Antropología Americana 49 (número especial): 183-208.

\section{Introduction}

In earlier work (Lacadena and Wichmann 2004), developing the seminal proposals of Houston, Stuart and Robertson $(1998,2004)$, we have argued that the Classic Maya scribe was able to distinguish between syllable nuclei containing a short vowel, a

\footnotetext{
1 Departamento de Historia de América y Medieval y Ciencias Historiográficas. Universidad Complutense de Madrid.

2 Leiden University \& Kazan Federal University \& Beijing Language University.
} 
long vowel, and a glottal stop, for instance in the following kinds of spelling where $a, a a$, and $a$ ' contrast.

K'AB'-b'a / k'a-b'a, $k$ 'ab' 'hand, arm'

B'AK-ki / b'a-ki, b'aak 'bone'

a-AN / AN-nu / a-nu, 'a'n 'spring maize, young ear of corn'

In this paper we would like to address the question of whether it was possible for the scribe to make the same kinds of distinctions in the suffix domain, i.e. to indicate differences among suffixes which are distinguished in their pronunciation only by the nature of the syllable nuclei that they contain. In other words, we shall address the question of whether the normal spelling rules extended to the suffix domain or were suspended, a question which has been at the core of an ongoing debate among epigraphers in the past years. Our answer to the question will be in the affirmative. We believe that the available evidence clearly demonstrates that the orthographic rules of syn- and disharmony («harmony rules» for short) extend to the suffix domain. We shall briefly summarize our five main types of arguments, some of which will be further substantiated in the body of the paper.

\subsection{Synchronic Pattern Consistency}

The exact same spelling patterns involving synharmony $\left(-\mathrm{CV}_{1}\right)$ and disharmony $(-\mathrm{Ci},-\mathrm{Ca}$, and $-\mathrm{Cu})$ that are attested in the spelling of nouns and adjectives are also found in the spelling of suffixed morphemes. Consider, for instance, the spellings of the following nouns, which all have an u-vowel in the final (or only) syllable:

k'u-hu, $k$ 'uh 'god'

cha-hu-ku, chahuk' 'lightning'

TUN-ni, tuun 'stone'

a-mu-chi, $a[j]$ muuch 'toad'

b'u-la, b'u' $[u] l$ 'bean'

HUN-na/hu-na, $h u$ 'n 'paper'

Here the $\mathbf{u}-\mathbf{u}$ pattern indicates a short $u$, $\mathbf{u}-\mathbf{i}$ a long $u u$, and $\mathbf{u}-\mathbf{a}$ an $u$ plus glottal stop (i.e., glottalized $u^{\prime}$ or glottalized and rearticulated $u$ ' $u$ ). Now compare the following spellings of forms all containing suffixes consisting of an u-vowel plus $l$ :

K'UH-lu / k'u-hu-lu, k'uhul, k'uh-ul 'holy'

u-K'UH-li, uk'uh[uu]l, $u$-k'uh-uul 'his god'

ma-su-la, $M a[h] s u$ 'l, Mahs-u' $[u] l$ 'place where the cricket abounds'

Since the spelling patterns are the same in the two sets of examples, we do not find any a priori reason to interpret them in different ways. Thus, we find no reason to assume that the normal spelling rules are suspended in the case of suffixes. In case of the examples just given there is no evidence against assuming that the patterns $\mathbf{u}-\mathbf{u}, \mathbf{u}-\mathbf{i}$, and $\mathbf{u}-\mathbf{a}$ also indicate respectively a short vowel, a long vowel, and a vowel plus glottal stop when they occur in the suffix domain. The Maya scribes clearly distinguished orthographically among the three suffixes, and we must ask why. 


\subsection{Diachronic Pattern Consistency}

Changes in the spelling patterns of nouns and adjectives which have been shown to indicate phonological changes such as loss of the vowel length distinction (Houston et al. 2004: 91-92, 97), the loss of the glottal stop (Lacadena and Wichmann 2004: 115-117), and the loss of the contrast between velar and glottal spirants (Grube 2004: 79-81) all recur in the spelling of suffixes. This is only expected if the same spelling rules apply to the lexical and the grammatical domain, but would otherwise be odd. To give some examples, the same process of vowel shortening is attested in b'a-ki > b'a-ka 'bone' and in K'AL-wi > K'AL-wa 'bind-antipassive'; a loss of the glottal stop is attested both in CHAN-nu > CHAN-na 'master, supervisor' and in uto-ma $>$ u-to-mo 'happen-future participial'; finally, both u-B'AH-hi $>$ u-B' AH-ji 'his image' and u-tz'i-b'i-na-ja-la > u-tz'i-b'i-NAH-ja-la 'his writing' bear witness to the loss of the $h: j$ contrast.

\subsection{General Agreement with Data from Alphabetically Recorded Mayan Lan- guages}

Data from modern Mayan languages, where different types of syllable nuclei (V, VV, V', Vh) are commonly found in suffixes, support the possibility that the language(s) of the Classic-period hieroglyphic inscriptions also made such distinctions. With respect to the Lowland languages the distinctions have mostly been lost. Thus, vowel length has become lost in Eastern Ch'olan, only survives indirectly and in the restricted context of mid vowels in Western Ch'olan, Itzaj, and Mopan, and has become lost in Yucatec precisely in the context of suffixes. Nevertheless, the opposition $a$ : $\ddot{a}(<* \mathrm{a}: * a a)$ in Western Ch'olan, Itzaj, and Mopan represents an important trace of the original opposition, and data from these languages clearly show the vowel length opposition to also have been operative in the suffix domain. Thus in Ch'ol, for example, - $\ddot{a} l$ is an absolutive suffix of a set of nouns, cf. bujc-äl 'camisa' (Aulie and Aulie 1978: 33) or c'äb-äl 'mano, brazo' (ibid.: 44), while -al is a suffix found in the possessed form of some derived nouns, e.g., $t z$ ' $i j b-a l$ 'dibujo, color' (ibid.: 122). Clearly, two different nominal suffixes *-al and *-aal must have existed in previous stages of the language. The situation is similar in Itzaj-Mopan, where proto-Yucatecan *a and *aa changed to *ä and *a. An example of the retention of the contrast in the suffix domain is provided by the allomorph -äl of the $-\mathrm{V}_{1} 1$ suffix for 'incompletive intransitive status' (Hofling and Tesucún 1997: 27, 45) and the -al intransitive participial suffix (ibid.: 172). For instances where the use of these suffixes lead to minimal pairs cf. jak'-äl uyool 'asustarse / take fright' (ibid.: 290) vs. jak'al uyool 'estar asustado / be frightened' (ibid.: 289). These forms must derive from earlier *jaak'-al vs. *jaak'-aal.

\subsection{Specific Agreement with Reconstructions Based on Data from Alphabeti- cally Recorded Mayan Languages}

Comparative linguistics provides the ultimate test of a given phonological interpretation of a suffix based on its orthographic rendering. When we count the number of matches between our orthographic interpretations of individual lexemes and linguistic reconstructions, we observe an agreement which on average is above 
$75 \%$ and for certain well-documented patterns reaches $85-95 \%$. This clearly does away with the possibility that chance is involved. Our suggestion that the general spelling rules also apply to the suffix domain should similarly be statistically supported. At present only a minority of suffixes in the inscriptions may be compared to reconstructed forms, either because the attestations of the suffixes in question are too limited outside of Ch'olan so as to make reconstructions possible or because the reconstructions, even if possible, have not yet been made. Nevertheless, when the earlier shape of a suffix is reasonably clear there usually is a good agreement with our phonological interpretations based on the inscriptions, suggesting that the over-all statistics for the performance of the harmony rules is as good as in the lexical domain. For instance, there is agreement between the reconstructions and our phonological interpretations of spellings in $95 \%$ of the cases where the a-i disharmonic pattern is in play and where nouns and adjectives are involved - as in the classic case of B'AK-ki / b'a-ki 'bone', for instance. Similarly, whenever the a-i pattern is involved in the suffix domain and comparative data allow for positing a reconstruction that specifies the nature of the syllable nucleus, the reconstructed syllable nucleus invariably entails the expected long vowel. Thus, the interpretation of the vowel in the plural suffix -TAK-ki / -ta-ki as being long is supported by data from modern Chontal, Ch'ol, Itzaj, and Mopan, which all have -tak (not*-täk). Similarly, the antipassive suffix, written LOGOGRAM-ni (as in u-UCH'-ni, uch'oon 'they drank') and interpreted by us as -[oo]n, is matched by the K'iche'an (K'iche', Tz'utujiil) and Mamean (Awakateko) shape of the antipassive suffix, which is also -oon. Finally, the long vowel of the suffix -uub' of ju-ku-b'i, jukuub', 'canoe' is matched by the similar K'iche'an suffix -uub' (cf. Q'eqchi' juukuub; Uspanteko and Pokomchi' jukuub').

\subsection{Epistemological Considerations}

All else being equal, the more desirable scientific hypothesis is the one which provides the simplest and most parsimonious account of the data. Our hypothesis has the advantage that it does not require any new orthographic principles to be posited other than the ones already established. Our assumption is simply that the Maya scribes operated with a system that was applied everywhere in their script without restrictions. Given the drawback of having to operate with orthographical principles that are not general, such as harmony rules that are sometimes suspended, it would require strong evidence to introduce restrictions and competing principles into one and the same orthographical system. We do not see any evidence requiring us to let go of a maximally simple and parsimonious account of the facts at hand.

The bulk of our paper will concentrate on demonstrating the validity of our first argument, the one regarding the synchronic patterning. As a way of showing that the differences in the hieroglyphic representations are systematic, we shall focus on instances of minimal pairs, i.e. pairs of suffixes that are spelled differently in ways suggesting that the only phonological difference concerns the nature of the syllable nuclei. These patterns provide internal evidence for our hypothesis that the normal spelling rules extend to the suffix domain. Regarding diachronic pattern consistency, the major pieces of evidence have already been cited above, and regarding general agreement with data from alphabetically recorded Mayan languages and specific agreement with reconstructions based on data from the modern sources more com- 
parative linguistic work is required to make a detailed statistics possible. Finally, the epistemological arguments, which involve a detailed discussion of the morphosyllable hypothesis, will be developed further in another paper.

\section{The Hypothesis: Expanding Harmony Rules to the Suffix Domain}

As already indicated, the present paper is a sequel to Lacadena and Wichmann (2004), where we proposed a revision of the orthographic theory of Houston, Stuart and Robertson $(1998,2004)$. In the theory of Houston et al., the 'silent' vocalic parts of syllabic signs serve to provide information about the pronunciation of the preceding syllabic nucleus even if the vowel as such is not pronounced. The authors argue that synharmonic complements normally indicate a short vowel, while disharmonic ones may indicate a long vowel, a vowel followed by $h$ or - potentially - a vowel followed by a glottal stop. The last possibility is said to usually be excluded because glottal stops tend to become lost in Ch'olan. Our revision has produced three harmony rules (i.e. rules of syn- and disharmony) which state, in general, that 1. synharmony indicates a short vowel, 2 . disharmony in $\mathbf{i}$ indicates a long vowel, and 3. disharmony in a indicates the presence of a glottal stop. When these general rules are in conflict some special ones set in. The more specific formulations of the disharmony rules, then, are: complementee-complementer combinations indicating a long vowel: i-a, e-i, a-i, u-i, o-i; combinations indicating a glottal stop: $\mathbf{i}-\mathbf{u}, \mathbf{e}-\mathbf{a}, \mathbf{a}-\mathbf{u}$, $\mathbf{u - a}, \mathbf{0 - a}$. One of the concomitants of the rules is that $\mathbf{C e}$ and $\mathbf{C o}$ signs may function only as synharmonic complements. As an additional new feature as compared with the harmony rules of Houston et al., we argue that a preconsonantal $h$ is never indicated by means of harmony rules.

In the paper we claimed that the harmony rules apply not only to the lexical domain, but also to the domain of suffixes. For example, if the vowel part of the complement ti in a form such as yo-OTOT-ti 'his house' serves to indicate that the second $o$ vowel in the word is long, we should equally expect the vowel part of, say, the syllabic sign li in u-to-jo-li 'his payment' to indicate that the last syllable of that word is long. So, just as we transliterate the first word yotoot we transliterate the second one utojool. This seems straightforward enough, although utojool is in fact a controversial transliteration. The alternative proposal (Houston et al. 2001: 14-23, 49, n. 4) is to view the li sign in to-jo-li as a sign standing for the suffix -il, which would produce the transliteration utojil. We strongly doubt the existence of such 'morphosyllabic' signs and are preparing a paper specifically addressing problems with the hypothesis concerning morphosyllables. In the present paper we mention some of the arguments against 'morphosyllables,' but our main focus is the elaboration of our own approach.

Whenever a lexical root is spelled syllabically (as the root toj 'to pay' of u-tojo-li 'his payment') and there is a suffix attached to the root, one syllabic sign in the string will do the double duty of spelling the end of the root and the beginning of the suffix. When a logogram is involved it is rarer to see a syllabic sign spelling both the last consonant of the lexical root and the beginning of the suffix. For spellings of this type there are often alternatives elsewhere in the corpus where the syllabic sign providing the orthographic 'ligature' is left out, conforming to the statistically preferred pattern: 
CHAK-WAY-ya-la, chak wayal (a personal name) [Piedras Negras]

CHAK-WAY-la, chak way [a]l [Palenque]

CH'AK-ka-ja, $c h$ ' $a-h-k-a j-\varnothing$, 'it was chopped down' [Tortuguero]

CH'AK-ja, $c h ' a-h-k-[a] j-\varnothing$ [Naranjo]

HAL-la-ja, hal-aj- $\varnothing$ 'it was manifested' [Quirigua]

HAL-ja, hal-[a]j- $\varnothing$ [Coba]

K'AK'-TIL-li-wi, $k$ 'a[h]k' ti[h]l-iw- Ø 'fire-it-burns' (a royal name) [Quirigua]
K'AK'-TIL-wi, k'a[h]k'ti[h]l-[i]w-Ø [Naranjo, Quirigua]
u-LAKAM-TUN-ni-li, u-lakam tu[u]n-il 'his banner stone' [Copan, Tikal, Tonina]
u-LAKAM-TUN-li, $u$-lakam $t u[u] n$-[i]l [Dos Pilas, El Peru]

There are two ways to interpret the shorter spellings. One is to see them as incomplete, in the sense that the readers have to supply the vowel themselves. This is the approach we prefer, and we have indicated by means of a square bracket that the vowels in the suffixes of the transliterations are the results of interpretation rather than elements that are already present in the spellings themselves. The other approach is to see the shorter spellings as complete in the sense that the vowel is supplied by the vowel of the final syllabic sign even if, under this interpretation, the final syllabic sign would have to be read backwards. For instance, in CHAK-WAY-la it would suffice to read the la sign backwards to get the $-a$ l. The way in which this approach in formulated by its advocates Houston et al. (2001) is that la should be viewed as a sign that has both a purely phonological value la and a combined phonological and morphological value as the suffix - al. If one can abstract from the ill-guided application of alphabetical principles to a system where the syllable is the minimal unit, the theory that the pronunciation of a syllabic sign can be reversed seems to work reasonably well in the above cases. In CHAK-WAY-la, CH'AK-ja, HAL-ja, TILwi, TUN-li we might be confronting signs that actually have the values -AL, - $\mathbf{A J}$, -IW, and -IL, respectively. But there are other pairs of spellings where the vowel of the last syllabic complement is not identical with that of the suffix and where the syllabic sign bridging the lexical root and the suffix may nevertheless also be left out:
u-CHOK-ko-wa, $u$-chok-o' $w$ - $\varnothing$ 'he scattered it' [QRG, SBL] u-CHOK-wa, $u$-chok-[o]'w- $\varnothing$ [AGT, CRC, CHL, DPL, PAL, PSD, PMT, QRG, SBL, TNA, UCN]

UN-ni-wa, uniiw (a month name containing the root un 'avocado') [CPN, PAL, PNG, SBL]

UN-wa, un[ii]w [NAR, PAL, PNG, RAZ, SBL, TIK, K6751, K1226]

Both members of the first pair clearly contain a suffix with the vowel $o$ and the consonant $w$, while both members of the second pair contain a suffix with a vowel $i$ and a consonant $w$. Thus, there are two different suffixes in play. According to the morphosyllable hypothesis, the wa sign in the spellings u-CHOK-wa and UNwa must then be interpreted as representing two different suffixes in addition to a purely syllabic sign. We find this very unlikely. According to our hypothesis, signs that represent grammatical affixes are exceedingly rare if not completely absent from the 
script. We might call ours the hypothesis of arbitrariness, since the central claim is that the relationship between signs and grammatical meaning is arbitrary (obviously arbitrariness does not hold for the lexical domain, where we find logograms, which stand for lexical morphemes). Under our interpretation spellings such as CHOK-wa and UN-wa are incomplete just like spellings like CHAK-WAY-la, CH'AK-ja, etc. in so far as the vowel of the suffix has to supplied by the reader.

The various pairs of spellings cited prove that the quality of the suffix vowel is independent of the vocalic part of the final syllabic sign, whether or not the two are identical. Some examples where there is identity between the quality of the suffix vowel and the vocalic part of the final syllabic sign are: CHAK-WAY-la, CH'AKja, HAL-ja. Here the pronounced vowel is $a$ and the written one is similarly a. Examples involving a pronounced vowel $i$ and a written vowel i are: K'AK'-TILwi, u-LAKAM-TUN-li. Contrasting with these are examples where the pronounced and the written vowel differ, demonstrating the mutual independence of the two. In CHOK-wa, for instance, the pronounced vowel is $o$ and the written vowel a, and in UN-wa the pronounced vowel is $i$ and the written one a. The straightforward interpretation of these facts is that the same orthographic principles of syn- and disharmonic complementation are at work in the suffix domain as in the lexical domain, i.e. when we are dealing with complementation of lexical items. In the suffix domain, however, a new situation sometimes arises, namely the situation where a logogram is involved and a vowel is underspelled and must be supplied by the reader. In such cases the rule obtains that any vowel may in principle be inserted - this depends on the knowledge of the reader-but whatever vowel it be, it is subjected to complementation by the following syllabic sign. For instance, any Maya reader would know that the vowel to be inserted into $\mathbf{U N}$-wa to fill up the space in $u n-w$ is an i-vowel, while we only know this because of the alternative spelling $\mathbf{U N}-\mathbf{n i}-\mathbf{w a}$. Once the question of supplying the missing vowel is resolved, the harmony rules are applied. The pattern i-(C)a tells us that the i-vowel is long. Thus, the correct interpretation is uniiw. Similarly, when the $o$ vowel is added to CHOK-wa, chok_w we get the reading choko' $w$ because the particular $o$-a pattern indicates an $o$ plus glottal stop.

We shall henceforth use intercalation as a technical term describing the process whereby a reader supplies a missing vowel.

Even if, in principle, any vowel may be intercalated into a LOGOGRAM-CV spelling, the effects of the harmony rules do produce some restrictions both on the quality of the vowel and the type of syllable which is the product of the final interpretation. Since Ce and Co signs do not enter into disharmonic complementation, a vowel inserted into a spelling of the type LOGOGRAM-Ce has to be a short $e$ and a vowel inserted into a LOGOGRAM-Co type spelling has to be a short $o$. When $\mathrm{Ci}, \mathrm{Ca}$, and Co complements are in play, however, there are no restrictions on the quality of the vowel; there are only restrictions on the possible type of vowel quality + syllable type combination. If, for instance, the complement is $\mathbf{C i}$, it produces the following restrictions on the nucleus type: an intercalated i-vowel must be short (synharmony), and an intercalated e-, a-, u- or o-vowel must be interpreted as long (disharmony, according to Harmony Rule 2). The full set of possibilities is as follows (Table 1): 
Table 1. The effects of intercalation

\begin{tabular}{ll}
\hline \multicolumn{1}{c}{ Syllable nuclei } & \multicolumn{1}{c}{ Complement } \\
\hline$i, e e, a a, u u, o o$ & (C)i \\
$e$ & (C)e \\
$i i, e^{\prime}, a, u^{\prime}, o$, & (C)a \\
$i, a, u$ & (C)u \\
$o$ & (C)o
\end{tabular}

So far the hypothesis has simply been presented as a logical extension of harmony rules of Lacadena and Wichman (2004). This extension of the system accounts for the fact that the vowels of final syllabic signs and those of the suffixes that they serve to represent are not always identical and it accounts in a parsimonious and falsifiable way for the orthographic rules of the Maya script. The next step is to show that the system as we see it is in fact applied in the script in such a way that one and the same affix is always treated in the same way (with due allowance for phonological changes over time) and such that the differential interpretation of non-identical suffixes is ensured. This step will provide script-internal evidence for the hypothesis and will be represented by the following section. Whenever possible, the results of the application of the spellings rules to the bulk of word-forms involving suffixes should be compared to extant language data. This will prove more difficult since, (a) in many cases, the suffixes of the glyphic corpus are not attested in extant languages that may provide evidence of vowel length or glottalization, (b) the comparative phonology of the Mayan languages is still not fully worked out, (c) the glyphic inscriptions are around a millennium earlier than most of the data for current Mayan languages and may be expected to preserve linguistic features that have been lost in the current languages.

\section{Internal Evidence for the Hypothesis}

In this section we shall present some examples of orthographic representations of affixes whose spellings differ only with respect to the «silent» vowel. We see such examples as providing internal evidence for our hypothesis that the «silent» vowels indeed have a function. For some of the examples there is also external evidence for the predictions brought about by the application of the harmony rules in the sense that reconstructions of the morphemes in question for relevant stages of the Mayan languages match our interpretations of the glyphic data. It is important, however, to distinguish between the internal, distributional evidence and the external, comparative evidence since the evaluation of the two kinds of evidence involve different types of arguments and thus cannot be weighed according to the same scales and also since it allows us to distinguish between situations where internal and external evidence are in agreement and situations where the two are in conflict. Given the advanced state of Mayan epigraphy as opposed to the somewhat less developed comparative Mayan linguistics ${ }^{3}$ we consider internal evidence to be stronger than external evi-

\footnotetext{
3 Some aspects of Mayan verbal morphologically has been studied diachronically, cf. especially Robertson (1992), but a published account of the full inflectional and derivational morphology of Mayan is lacking. The unpublished study by Kaufman (1986) is a step towards a manual of this sort, but is nevertheless incomplete and in several crucial cases it is difficult to judge whether the author is reconstructing abstract, underlying phonological shapes
} 
dence. If, for example, a spelling clearly indicates the presence of a long vowel in an affix which has been reconstructed as having a short vowel and is treated differentially in the script from another affix which, however, has been reconstructed as having a shape identical to that of the first affix, we are more prone to consider the reconstruction wrong than to be throw out the entire orthographic system that has emerged from the study of the script. In the following, then, we shall present some minimal pairs. We begin with the best examples, where there is external evidence for at least one of the members of the pairs and finish with less clear examples, where there are problems with the external evidence or difficulties relating to the interpretation of the glyphic examples. The examples are limited to cases where derivational bases for the pairs pertain to the same parts of speech, i.e., cases where different spellings arguably serve to disambiguate phonologically different forms.

\section{1. -il 'Abstractive' vs. -iil 'Toponymic'}

The first member of this pair is the well-known abstractivizing suffix -il. This appears both in the codices and on monuments. In the codices we have the expression HAB'-li, $h a b$ '-[i]l 'season' (e.g., Codex Madrid, 54A, 66A-B, 68B, D71A, 109B), which enters into different expression, including K'IN-TUN-HAB'-li, $k$ 'intunhab 'il 'dry season, time of drought' (Codex Dresden). As observed by Lacadena (1997), K'IN-TUN is ambiguous with respect to the language it represents - $\mathrm{cf}$. Ch' ol q'uin tunil 'tiempo de seca' (Aulie and Aulie 1978: 102) and Yucatec $k$ 'intunya'abil 'verano, tiempo de seca' (Barrera Vásquez 1995: 404 citing the Diccionario Motul as well as other sources); -il is likewise represented in both of the families belonging to the Lowland Languages sphere. The codices also exhibit the augury glyph yutzi-li, yutz-il 'goodness' (e.g. Madrid, 16A, 40B, 41 A, 41C, 42C, 49C, 50C, 63B, $71 \mathrm{~B}, 101 \mathrm{C}, 103 \mathrm{~B}, 106 \mathrm{C}$ ), where the same $-i l$ suffix is at work, this time spelled in a full syllabic manner giving script-internal evidence for the -il shape. In Ch'olan inscriptions of the Eastern vernacular area we have the expression AJAW-il, ajaw-

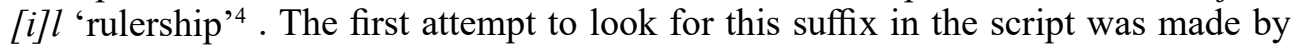
Thompson (1971 [1950]: 269-271), but it did not become properly identified until phonetic decipherment by David Stuart had established the value of the various li signs (cf. Stuart 1987: 41, 47; Schele 1993: 17).

The other suffix was identified more recently (in a message sent by Wichmann to fellow epigraphers in January 2000). This is a suffix which appears on several place names in the Western Ch'olan region, i.e. the following:

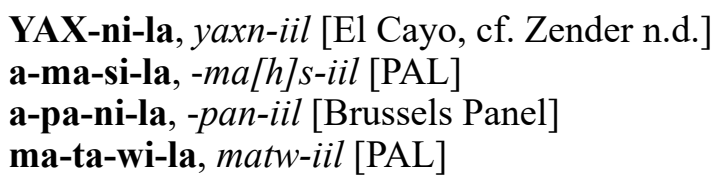

for a given affix or whether he is positing actual realizations. Thus, the kind of information we need for the present purposes concerning vowel length and presence or absence of glottal stops is not easy to retrieve. Finally, a treatment of morphophonemics of vowel length establishing a historical background for the way that the different languages behave with respect to the interaction between lexical roots and suffixes would have been helpful but is not provided.

4 The instances registered by Lacadena and Wichmann (2002: Section 5.1.2 and Table 6) are all before A.D. 700. Houston et al. (2001: Fig. 9a) cite an additional example, namely one from Aguateca St. 15. This might be the latest known example, since all other known monuments are later than 740 A.D. 
Before discussing the meaning of each of this place names we should try to define the function of the suffix. That there is in fact a suffix of a similar shape associated with Ch'olan place names is documented by Warkentin and Scott (1980: 118-119), who mark off several place names in -il on their map of Ch'ol villages: Joñajil, Jo'xil, Yäxlumil, and Joljamil. The suffix also serves to build forms meaning X-yard, where $\mathrm{X}$ is a plant, fruit, crop, etc. A couple of examples are alaxax-il 'naranjal' (Aulie and Aulie 1978: 29) and C'olol-il 'arboleda de encino, nombre de una colonia' (ibid.: 43). We take it, therefore that -iil means 'place where $\mathrm{X}$ abounds'. A cognate of the suffix is documented for Itzaj, cf. the following passage in Hofling and Tesucún (1997: 23):

«Nouns derived with -il may also indicate 'part of', 'place of' and 'place of origin' relations (...). For example, (...) k'uumil n3b, ayotal, squash plot, squash patch, is derived from k'uum (1a) n1a, calabaza, ayote, squash, gourd, ayote, and ixKob'anil adjn2cib/3b Cobanera, woman from Coban, is derived from Kob'an pn, Coban, Coban. Note that in examples indicating place of origin, the derived noun has a noun classifier prefix, like other adjectival nouns, as well as the -il suffix».

A number of place names on the Yucatan peninsula, some of them well known among Mayanists, provide further attestations of the suffix and shows that it is widespread in the Lowland languages, e.g.:

Sayil 'place where the argentine ant abounds',

cf. $h$ sàay 'argentine ant' (Bricker et al. 1998: 243)

Xpuhil 'place where the reed abounds',

cf. Itzaj puj 'rush, reed' (Hofling and Tesucún 1997: 525)

Muyil 'place where the ... tree abounds',

cf. the list of tree names in Bricker et al. (1998: 191) compounded with mùuy as the second member.

The name Yaxniil could be a contraction of a form such as yaxun (or yaxuun), which, according to Schele (1991) was first proposed by N. Grube as the decipherment of the first part of the name of the Yaxchilan 'Bird Jaguar' personages. The semantic interpretation is apparently based on ethnohistorical sources, cf. the mentioning of a ritual object called yaxum in the Book of Chilam Balam of Chumayel, which is translated by Roys (1967: 73) as 'quetzal'. Doubt concerning the correctness of the decipherment of the logogram earlier read YAXUN has lately propagated among epigraphers (Martin and Grube 2000, for instance, refrain entirely from using it), but a discussion of background for this change in the epigraphic purview is not of direct interest here, since we are simply concerned with finding a suitable candidate for the noun to which -iil attaches in the name yaxniil, an expression which does not involve that logogram. An item similar to the yaxum of the Chilam Balam of Chumayel item might be a candidate although this hypothesis is difficult to develop further since the Chumayel form is rendered with a final $m$ and since is it semantically illdefined (the standard lexicographical sources on the Lowland Languages universally fail to list it). Other candidates might be Ch'ol yaxum 'maíz negro' (Aulie and Aulie 1978: 42), Lacandon yaxäm 'tortuga grande' (Canger 1970), Chontal yäxoma 'acahual, bosque' [where the final $a$ is surely a suffix] (Keller and Luciano 1997: 269). All of these, however, also suffer from the problem that the final consonant is $m$ and not $n$. An intriguing form is the surname Yaxoon used in the towns of Sta. Lucía Uta- 
tlán Nahualá and Santa Catarina Ixtahuacán listed without further semantic definition in Ajpacaja et al. (1996: 516). This form could well be cognate with a hypothetical Classic Ch'olan yaxuun, and even if its meaning is unknown it is not a far shot to suppose that it is an archaic animal name (possibly a bird name), given the preponderance of names referring to animals among the modern as well as the ancient Maya.

For $\mathrm{Ma}[\mathrm{h}]$ siil the only likely candidate root in the entire Mayan lexicographical corpus would be one meaning 'cricket', cf. Yucatec $h$ máas (Bricker et al. 1998: 180) and Lacandon maas 'grillo' (Canger 1970). The likely meaning of this toponym, then, is 'place where the cricket abounds'. The high tone in the Yucatec form usually corresponds to a preconsonantal $h$ in Ch'olan, which is why we posit this $h$ in the transliteration.

For Paniil the only likely candidate is the form reconstructable as proto-Mayan *pan 'toucan', cf. Ch'olti' pan 'pájaro de pico amarillo' (Moran 1695: 156), Ch'orti' pan 'parakeet' (Wisdom 1950), Yucatec pan 'ave de pico muy ancho y largo; pito real o tucán' (Barrera Vásquez 1995: 628 citing J. Pío Pérez; the entry furthermore cites scientific names of three species identified by P. C. Standley), Lacandon pän / pan 'tucan' (Canger 1970, whose notations of this vary, although both variants point to a short a), Q'anjob'al pan 'tucán' (Diego Antonio et al. 1996), and Akateko pan 'tucán' (Andrés et al.: 1996: 128). The meaning of Paniil would then be 'place where the toucan abounds'.

The shape of the last form, Matwiil, was posited as such in Wichmann's January 2000 message on the purely phonological grounds that pretonic syllables tend to syncopate, but Stuart's (2000: 15) decipherment of a sign MAT depicting a cormorant, which enters into an alternative spelling MAT-wi-la of the word more commonly spelled ma-ta-wi-la, confirms the phonological interpretation. Unfortunately the meaning is more difficult to narrow down than the pronunciation. It is not a given that the meaning of the place name has anything to do with cormorants. There is a non-retrievable syncopated vowel following the string mat, such that the underlying form should be mat $V(V)$ wiil. Thus, either a $-V w$ or $-V V w$ shaped suffix is in play or else the root is $\operatorname{mat} V(V) w$.

\section{2. -ul Allomorph of - $V_{1} I$ 'Attributivizer' vs. -uul Allomorph of - VV $V_{1}$ 'Suffix on Certain Possessed Nouns' vs. -u'ul 'Toponymic'}

In this section we shall consider not only a minimal pair, but a whole triplet of contrasting forms.

There is no need to discuss the first member of triplet in detail since it has already been documented extensively by Houston et al. (2001: 32-36). The affix in question is the attributivizer, which takes the shape $-\mathrm{V}_{1} 1$, where the quality of the vowel mirrors that of the root. For our present purposes the $-u l$ allomorph is the more important since the double contrast it provides with the -uul allomorph of the $-\mathrm{VV}_{1} 1$ suffix on certain possessed nouns and the $-u$ ' $u l$ toponymical suffix is one more piece of internal evidence that 'suprasegmental' features of suffixes were distinguished. The best example ${ }^{5}$ of the $-u l$ allomorph is K'UH-lu, $k$ ' $u h-[u] l$ 'holy'. We doubt

\footnotetext{
Houston et al. (2001: 34) also list a b'u-b'u-lu-HA' (PNG, Pan. 2, J'1) as an instance of the -V 1 ladjectival suffix and give as possible alternative meanings 'he of the frothy water' (Zender 1999: 115) and 'he, the water bug'. We suspect that both translations are either imprecise or wrong. The idea relating to the sense 'frothy', although
} 
that Houston et al. (2001: 35) are correct in their statement that «the k'uhul sign appears to change value depending on position; as an adjetive it reads $k^{\prime} u h u l$, as a noun $k^{\prime} u h$ ». Instead we prefer instead to see all occurrences (in Ch'olan contexts) as K'UH and the adjectival instances as underspellings ( $\left.k^{\prime} u h[-u l]\right)$. Nevertheless, we are in agreement about the shape and the nature of the suffix.

The attributive suffix enters into a perfect minimal pair with the $-V_{1} 1$ suffix of possession since both may attach to the root $k^{\prime} u h$. Thus, u-K'UH-lu POSSESSOR contrasts with u-K'UH-li POSSESSOR. The first is found in expressions such as $u$-k'uh-[u]l k'ab'a' 'its holy name' and the last in $u$-k'uh-[uu]l NAME 'the god of NAME' (Jackson and Stuart 2001). Obviously -ul vs. -uul are just special instances of the contrast between these two vowel-harmonic suffixes. An example of a contrasting pair involving another vowel, in this case $o$, is po-po-lo, $p o[h] p$-ol 'matty' (Yaxchilan, HS 3, Step I, E1) vs. u-wo-jo-li, u-woj-ool 'its glyphs' (Chichen Itza, Xcalumkin).

The third member is spelled either ...-(C)u-la or LOGOGRAM-la. In many cases it is underspelled (or abbreviated), just like the lu sign is usually lacking with K'UH even in adjectival use. The relevant set of spellings is the following:

a-ku-la, $A[h] k u$ ' $[u] l$ [Comalcalco] / AK-la, $A[h] k[u]$ ' $[u] l$ [Palenque] / a-ku, $A[h] k u$ '[ul] [Arroyo de Piedra, Naj Tunich] / a-ku-u-lu, $A[h] k u$ 'ul [K4169]/ a-ku-lu [Bonampak] 'turtle-lineage'

pa-ka-b'u-la / pa-ka-b'u, Pakb-u'ul 'Pomoná'

ma-su-la (in emblem glyph [Calakmul]) / 4-ma-su (part of name [Tonina]), $m a[h] s u$ 'ul

KAN-la, Kan [u]' [u]l/ KAN, Kan[u'ul] 'Calakmul'

MUT-la, Mut [u]' [u]l/ MUT, mut [u'ul] 'Tikal'

The list as a whole shows that a suffix consisting of an u-vowel and an $l$ is often associated with place names and family names. The fact that it is treated orthographically different from the -ul of $k^{\prime} u h-u l$ and the -uul of chumuul strongly suggests that the harmony rules are at work. The only other potential explanation for the difference is to see the toponymic/patronymic suffix in play as a morphosyllable -AL,

not detailed fully by its author, must have departed from the transitive verb reconstructable as proto-Mayan *b'ul 'to fill' (Wichmann and Brown 2004), which comes out as b'ul-ul 'bulking' (abultado) in Ch'ol (Aulie and Aulie 1978: 34) and b'ul 'to sink, submerge' in Yucatec (Bricker et al. 1998: 38). A process of reduplicating the first CV part of the root is neither attested in Ch'ol nor in other Ch'olan languages, however, so $b^{\prime} u b^{\prime}$ ' $u$ lis unexpected here. What we instead get is Ch'ol b'ulb'ulña 'relacionado con la forma en que brota el agua' (Aulie and Aulie 1978: 34). In Yucatec we do have the kind of reduplication process that would produce $b$ ' $u b$ ' $u l$, and this form is also attested; there is in fact an entry: b'ub' 'ul-ha' 'tearful, watery (moon)' (Bricker et al. 1998: 38). While highly interesting in itself, since this shows that under certain meteorological circumstances the moon is seen as submerged in water just like the case is among the K'iche's, the Ch'orti's, and the Classic Mayas (cf. Wichmann 2004), the entry is hardly relevant since the whole phrase is an adjective and would thus not work with $a j-$. The suggestion relating to water bugs must have departed from the entries Ch'ol bujb 'renacuajo' (Aulie and Aulie 1978: 33) and Mopan bub 'renacuajo, tepocate' (Ulrich and Ulrich 1976: 34). This suggestion may be brought to work, but not if the suffix is taken to be the adjectival - $u l$ since 'tadpole-like water' is hardly an option. Instead, we think that the $-u l$ might be a phonologically evolved form of the toponymical suffix $-u$ ' $l$ to be discussed below. Our only concern is that it would be a rather early instance of the change $V^{\prime}>V$, since Piedras Negras Panel 2 dates to 9.11.15.0.0 (A.D. 667), around half a decade before other instances (Lacadena and Wichmann 2002: Table 4). A translation of $A[j] B$ ' $u[h] b$ ' $u l ~ H a$ ' as 'He of the Water Where the Tadpole Abounds' is acceptable semantically and the form would fit the set of other forms relating to various kinds of animals, such as Kanu'ul, Mutu'ul, etc. In fact, there is a completely parallel expression on El Cayo, Altar 4, Supports: YAX-a-ku / la-HA', Yax A[h]ku' $[u] l \mathrm{Ha}$ ' 'Green Water Where the Turtle Abounds'. 
as Houston et al. (2001: 51, n. 12) do. However, we find it is counterproductive to disprefer an interpretation which in better line with attested linguistic forms. An -al suffix on toponyms is not inherently impossible, but a suffix having an u-vowel is actually attested in forms that are similar to those in the inscriptions. Thus, there are place names similar to Mutu'ul, i.e. the Motul of northern Yucatan and the Motul de San José of Central Petén. In Barrera Vásquez (1995: 712, citing Ralph Roys) we learn that the name of the founder of Yucatan's Motul is called Sak Mutul, which brings us even closer to the in pronounciation to the glyphic Mutu'ul. We also have the place- and personal name Canul, which is similar to our interpretation of the name of Calakmul, Kanu'ul. And finally Ahku'ul brings to mind the Pasión region toponym San Juan Acul (Houston 1993: 116). With the probable exception of San Juan Acul the modern names obviously do not refer to the same particular localities as the Classic place names, but it is completely expected for particular toponyms to be so popular as to be used for different places. Toponyms and personal names are known to be conservative, sometimes remaining even after the languages that produced them are gone ${ }^{6}$, so these correspondences are hardly a coincidence. It would be strange, however, to find anciently attested names such as Mutal, Ahkal, and Canal alongside modern names such as Mutul, Akul, and Canul. Since they assume that the final la sign in such spellings as the ones we list above are really a morphosyllable -AL, Houston et al. (2001: 51, n. 12) fall victim to Systemzwang and lump YAX-nila together with MUT-la etc. But it is difficult to imagine how YAX-ni-la is even to be pronounced if it is to contain an -al, and Houston et al. simply leaves this up to the imagination of the reader. Is it to be pronounced Yaxnal or maybe Yaxnial? The question extends to other forms, since, as shown above YAX-ni-la patterns morphologically and geographically with -ma-si-la, a-pa-ni-la, and ma-ta-wi-la. Are the others, then, to be pronounced Masal, Panal, Matwal or, even worse, Masial, Panial, Matawial? And if so, what is the $\mathbf{i}$ part of the different $\mathbf{C i}$ signs doing-does it indicate some morpheme or is it maybe just to be ignored? Clearly this approach creates far more problems than it solves.

There are several instances of a suffix written $<-$ ul $>$ in older sources for Yucatec listed in the Diccionario Maya edited by Barrera Vásquez. Among the following examples the first is of particular interest because it shows the likelihood that a glottal stop is actually present in this suffix. The set as a whole also serves to demonstrate that there is an overlap, and sometimes a direct relationship, between toponyms and patronyms:

- cholul 'Apoplanesia sp, un aleguminosa de madera dura y flexible, usada en la antigüedad para fabricar arcos de flecha' (Barrera Vásquez 1995: 107, citing his own information). This is alternatively given as choluul and, citing, Domingo Dzul Poot, as chuluul). These alternative forms suggest that the suffix contain a glottal. A form which is probably of the same shape is given as the next entry in the Diccionario Maya, namely cholul 'toponímico. Población que pertenecía a la provinvia de Keh Pech; está localizada al norte de Mérida; [su nombre se refiere posiblemente a la planta del mismo nombre]' (ibid., citing Ralph Roys).

\footnotetext{
As is the case with many toponyms in Europe or; for a Mesoamerican parallel, there are the old Xinca toponyms in El Salvador or, for that matter, the case of Yax Ha'.
} 
- kupul '[toponímico]; kup: Calopogonium coeruleum, Benth; jícama cimarrona, jícama de monte; la provincia yucateca más densamente poblada y una de las más extensas durante la conquista española, su nombre proviene del linaje Kupul... (ibid.: 354, citing Ralph Roys).

- k'umul 'patronímico' (ibid.: 423).

- muk'ul 'patronímico maya...' (ibid.: 538).

Among some Western Mayan languages there are toponyms in -ul, showing that the use of this suffix by Ch'olans is not necessarily due to Yucatec influence, e,g, Q'anjob'al Chinajul Chinab 'jul, and Ewul (all toponyms listed in Diego Antonio et al. 1996) and Akateko Q'anul and Chajul (listed as toponyms in Andrés et al. 1996) (unfortunately Q'anjob'al and Akateko cannot show evidence for the glottal stop since this is generally lost in both languages). We shall now go on to commenting on the individual Classic toponyms/patronyms.

The first, $A h k u$ 'ul, provides a whole orthographic paradigm of possible spellings, all conforming to the conventions of Maya writing. We have a-ku-la, where the only underspelled element is the preconsonantal $h$, a kind of element usually not represented in the writing system (Lacadena and Wichmann 2004: 104-108). We also have AK-la, where the logogram signifying ahk 'turtle' is followed by the indicator of the last consonant of the suffix, but where the vowel of that suffix has to be supplied by the reader. The spelling a-ku represents the same kind of underspelling, leaving out the la sign, but in a context where the previous sign is a syllabic one. We also have a full spelling a-ku-u-lu, where the $\mathbf{u}$ part of the final syllabic sign complements the preceding $\mathbf{u}$ sign. As explained in Lacadena and Wichmann (2004: 111-113), CV'VC roots may either be complemented synharmonically, to indicate the final, short vowel (CV'VC) or disharmonically, to indicate the glottal stop $\left(\mathrm{CV}^{\prime} \mathrm{CV}\right)$. This was a matter of choice of analysis on the part of the Mayan linguists, some of whom analyzed the $-\mathrm{V}^{\prime} \mathrm{V}$ - sequence as a divided between two syllables, and others of whom analyzed $-\mathrm{V}^{\prime} \mathrm{V}$ - as a whole syllable nucleus in its own right. The spelling a-ku-u-lu represents the former kind of analysis and a-ku-la the second. The example of a-ku-u-lu is very important since it proves that there is a glottal stop at work, and it also helps us to specify that the nucleus is - V'V- rather than just -V'-. The evidence which perhaps best demonstrates that a-ku-la cannot be interpreted as containing an -al suffix is constituted by two variants of the names of a royal woman at Bonampak (pointed out to us by S. Guenter in personal communication): IX-a-ku-la pa-ta-ha-la (Stela 2) and IX a-ku-lu pa-ta-ha (Stela 1). In the former variant $a[h] k u$ ' $[u] l$ is intended, and in the latter $a[h] k u l$. The difference is due to the historical loss of the glottal stop. The spelling a-ku-lu would make no sense if the suffix involved were -al.

Given the overlap of functions of the Yucatec $-u^{\prime} u l$ suffix as either patronymical or toponymical we find it reasonable that glyphic $A h k u$ 'ul should patten with Pakb'u'ul, Mahsu'ul, and Kanu'ul even if Ahku'ul functions as a patronym and the others as toponyms ${ }^{7}$. A sharp distinction should be drawn between the suffixed form

\footnotetext{
It would be interesting to study the relationship between patronyms and toponyms in a Mayan and perhaps a wider Mesoamerican context to see whether lineage names derive from place names or the other way around. Our feeling is that the place names may be more fundamental, although we presently lack evidence for this hypothesis. In any case, $A h k u$ 'ul appears both in personal and place name contexts.
} 
Ahku'ul 'turtle-lineage' and the word ahk 'turtle', which is spelled a-ka (Tonina, Stucco frieze, cf. Stuart 1998: 394, note 11).

The next item, pa-ka-b'u-la / pa-ka-b'u, pakb'u'ul, the name of Pomoná, is reminiscent of a-ku-la / a-ku in the sense that there is a full as well as an abbreviated version - something which also goes for the third item ma-su-la vs. ma-su, to which we shall return shortly. It seems to be a derivation of the form pakab', attested in Ch'orti' as <pacab> 'wooden beam' in the confesionario of Moran (1695: 68-69) and in the vocabulary as < pacabte> 'tirantes de la casa'. In Yucatec we have pakab (Barrera Vásquez 1995: 620), which refers to wooden boards in various functions: as attics, benches, lintels, etc. Thus, the meaning is something like 'Place of Many Wooden Boards' or even 'Place of Many Wooden Lintels', if this second translation is not too narrow. We should note, however that there is also a Wasteko form pakab 'sugarcane' with a Chicomucelteko cognate of the same shape and meaning. Even if the item is not attested outside of Wastekan it is not impossible that Wastekans could have given name to the place sometime before they migrated north. Even if 'Place of Many Wooden Lintels' is attractive for someone interested in epigraphy, 'Place Where the Sugarcane Abounds' seems more in line with the tendency for toponyms to refer to natural phenomena. Perhaps we shall never know which of the two is the correct solution.

The next item ma-su-la / ma-su probably contains the same root as that of a-masi-la discussed above, name mahs 'cricket'. The meaning of the two places would seem, then, to be essentially the same: 'Place Where the Cricket Abounds'.

Inevitable we have to extend the interpretation to the places KAN / KAN-la and MUT / MUT-la, even if it with some trepidation that we propose new pronunciations of the names of these, the two champions of Maya cities: Calakmul and Tikal. There seems no reason to doubt, however, that these were respectively called Kanu'ul and Mutu'ul, even if epigraphers in the past have preferred Kanal and Mutal or simply Kan and Mut. Again we see abbreviations occurring, and in these cases the forms that are the statistically far preferred are the abbreviated ones KAN, Kan [u'ul] and MUT, Mut [u'ul]. We do not find it strange that such names should be abbreviated since it is a linguistic universal that the length of a word is inversely proportional to its frequency (Zipf 1949). We find it significant that abbreviations in Mayan inscriptions are more frequent in the areas of (personal and place) names, where the context is so narrow that ambiguities are never an issue. This supports the hypothesis that we are in fact confronting abbreviations rather than variation in speech. One may be in doubt whether the abbreviation of the $-u$ ' $u l$ is to be understood as a convention is the same way that St., S[tree]t or Mr., M[iste]r, etc. are in our own script or whether it is simply the case that any word may in principle be abbreviated by leaving out a final syllabic sign. While the latter is probably the more correct interpretation, it is still of interest that the majority of abbreviated forms belong to the category of names. As for the meanings of the original names of Calakmul and Tikal there are no difficulties. Kanu'ul must mean 'Place Where the Snake Abounds', and Mutu'ul would mean either'Place Where the Bird Abounds' or, considering the shape of the MUT logogram, something like 'Place of Hair'. The 'snake'-word goes back to proto-Mayan and should, on the basis of Yucatec evidence, be reconstructed with a long vowel (cf. Kaufman and Norman 1984: 117, \#075). Thus Ka[a]nu'ul might be the linguistically correct transliteration, although we hesitate to insist on this since it is not certain whether the affixation of $-u^{\prime} u l$ affected the length of the root such that Kanu' $u l$ was, after all, the proper pronunciation. The generic word for 'bird', mut, is 
likewise an old one, attested throughout the Greater Lowland languages, as well as in Chuj and Tojolab'al, and is reconstructable for this segment of the Mayan family simply as *mut (Kaufman and Norman 1984: 126, \#338). The meaning is generic across the board (except in Tojolab'al where is shifted to 'cock/hen', according to Lenkersdorf 1979), but for Ch'orti', Wisdom (1950) informs us that there is nevertheless a restriction on its use since it excludes vultures. The other meaning of mut is apparently only attested as Yucatec mut pol, which refers to a certain style of hairdo (Diccionario de Viena, cited in Barrera 1995: 542). If this is the meaning referred to by the logogram then the place name would be similar to Central Mexican ones like Tzontlan or Tzontepec.

At this point we should mention another name B'AK / B'AK-la 'Palenque'. Even if we cannot be certain about the final interpretation the examples provides a good opportunity to rehearse the principles that we are advocating. Given the suggested rules for the interpretation of LOGOGRAM-CV type spellings there are five potentially possible basic interpretations of B'AK-la: (1) $B^{\prime}$ 'a(h)kiil, (2) $B^{\prime} a(h) k e^{\prime}(e) l$, (3) $B^{\prime} a(h)$ $k a l$, (4) $B^{\prime} a(h) k u^{\prime}(u) l$, and (5) $B^{\prime} a(h) k o{ }^{\prime}(o) l$ (parentheses signalling possibilities to add to the basic ones). If the attested patterns may be used as guides for interpreting the form, the two most likely possibilities are $B^{\prime} a(h) k i i l$ and $B^{\prime} a(h) k u$ 'ul. There is little to help us in choosing, but since there is a strong tendency to prefer toponyms in -iil in the geographical area to which Palenque belongs (cf. above) we find this possibility more likely. There are many different roots in b'ak throughout Mayan languages, but the one that offers the best match with the expectations we have developed by now of a toponym describing some natural phenomenon (most often an animal), is the root b'ak 'heron' (attested as Yucatec bak 'garza' in Barrera Vásquez 1995: 27). Thus we think that the original name of Palenque was bakiil 'Place Where the Heron Abounds', although this interpretation must remain inconclusive.

\section{3. -ool 'Allomorph of $-V V_{1} l$ 'Participial of CVC Transitives and Positionals' vs. -o'l Allomorph of $-V_{1}$ 'I 'Nominalizer of CVC Transitives'}

In this section we would like to compare the following two spellings:

jo-ch'o-li, joch'-ool- $\varnothing$ 'drilled' (Ek' Balam, Col. 1)

CHOK-ko-la, chok-o’l 'casting, scattering' («Site Q» Panel, cf. Mayer 1989: Pl. 110)

Since in both cases the suffixes are spelled out in full there is no room for speculation concerning their shapes. When applying the harmony rules we obtain two different suffix shapes: -ool, and -o'l. In both cases a CVC transitive root is in play (joch' 'to drill' and chok 'to scatter'). The participial enters into the sentence joch'0-li K'AK', joch'-ool- $\varnothing k^{\prime} a[h] k$ ' 'fire is drilled', where reference is made to a fire ceremony, and the nominalized form is attested as part of the expression $\mathbf{u}-\mathbf{b}$ 'a / ti-CHOK-ko-la, $u$ b'a[ah] ti choko' l 'it is his image in scattering' on Site Q Panel (cf. Mayer 1989: Plate 110).

\section{4. $-V_{1}$ 'w 'Thematic of CVC Transitives' vs. $-V V_{1} w$ 'Antipassive'}

The first member of this pair is a suffix that serves to indicate the declarative status of the CVC transitive verbs. It has been known since Victoria Bricker identified it in 
her 1986 A Grammar of Mayan Hieroglyphs as a suffix -aw, which she described it as «some kind of transitive suffix» that goes with «root transitive verbs») and related it to Tojolab'al $-V(w)$, a transitive verbal marker (Bricker 1986: 126). The spelling rules that we are advocating allow for two possibilities for interpreting the pronunciation of this suffix, which is glyphically spelled wa.

One possibility is that that the spelling conventions indicate a vowel-harmonic suffix containing a glottal stop. Given that a $-V_{1}$ w suffix having a short vowel could be spelled LOGOGRAM-wi, LOGOGRAM-we, etc. or ...Ci-wi, ...Ce-we, ...Cawa... etc., i.e. with synharmony indicating a short vowel, just like the vowel-harmonic adjectival suffix discussed above, which is variously spelled with li, le, la, lu or lo signs, and that a $-V V_{1} \mathrm{w}$ suffix could be spelled with wi and wa signs (the former after roots with the vowel $e, a, u$, and $o$ and the latter after roots with the vowel $i$ ), we believe that the wa spellings could indicate the third possibly kind of nucleus, namely the glottalized one. The following spellings would indicate a glottal stop in the five potentially possible allomorphs of a suffix of the shape $-V_{1}$ w: ...-Ci-wu, ...-Ce-wa, ...-Ca-wu, ...-Co-wa, ...-Cu-wa. We do not, however, in all cases get the expected spellings. Table 2 is a comparison of the expected and the attested patterns. The cases where the expected and the attested patterns do not match up are marked off by a special frame in the table.

Table 2. Expected and attested patterns of the declarative suffix of CVC transitives

\begin{tabular}{|c|c|c|}
\hline $\begin{array}{l}\text { Expected spellings } \\
(\mathrm{Lv}=\text { logogram in a } \\
\text { given root vowel V) }\end{array}$ & Attested spellings & Examples \\
\hline $\begin{array}{l}\ldots \text {..-Ci-wu, }-i^{\prime} w \text { or } \\
\mathrm{Li}_{\mathrm{i}}-\mathbf{w u},-\left[i^{\prime}\right] w\end{array}$ & $\ldots$-Ci-wa, $-i['] w$ & $\begin{array}{l}\text { u-ti-mi-wa, utimi[']w 'it satisfies it' [M. Zender } \\
\text { and B. MacLeod in personal communication] }\end{array}$ \\
\hline $\begin{array}{l}\ldots \text {-Ce-wa, }-e^{\prime} w \text { or } \\
\text { Le-wa, }-\left[e^{\prime}\right] w\end{array}$ & ...-Ce-wa, $-e^{\prime} w$ & $\begin{array}{l}\text { u-je-le-wa, ujele' } w \text { 'he adorned it' [PAL, T.I., cf. } \\
\text { Chontal jel- vt. 'to adorn'] }\end{array}$ \\
\hline \multirow[t]{8}{*}{$\begin{array}{l}\ldots-\mathbf{C a}-\mathbf{w u},-a^{\prime} w \text { or } \\
\mathrm{L}_{\mathrm{a}-\mathbf{w u}}-\left[a^{\prime}\right] w\end{array}$} & $\begin{array}{l}\ldots-\text {-Ca-wa, } a['] w \\
/ \text { La-wa, }-a{ }^{\prime} w\end{array}$ & u-CH'AM-wa, ucham [a']w 'he took it' \\
\hline & & u-ka-cha-wa, ukacha[']w 'he tied it' \\
\hline & & u-K'AK-wa, uk'ala[']w 'he wrapped it' \\
\hline & & u-na-ka-wa, unaka[']w 'he conquered it' \\
\hline & & u-pa-ta-wa, upata['] $w$ 'he formed/made it' \\
\hline & & u-TZAK-wa, utzak[a']w 'he conjured it' \\
\hline & & u-tza-pa-wa, utzapa[']w 'he planted it' \\
\hline & & ya-YAL-wa, yal $\left[a^{\prime}\right] w$ 'he threw it' \\
\hline \multirow[t]{3}{*}{$\begin{array}{l}\ldots-\mathbf{C u}-\mathbf{w a},-u^{\prime} w \text { or } \\
\mathrm{Lu}_{\mathbf{u}}-\mathbf{w a},-\left[u^{\prime}\right] w\end{array}$} & $\begin{array}{l}\ldots-\mathbf{C u}-\mathbf{w a},-u^{\prime} w \\
/ \mathrm{Lu}_{\mathrm{u}}-\mathbf{w a},-\left[u^{\prime}\right] w\end{array}$ & u-b'u-t'u-wa, $u b^{\prime} u t^{\prime} u^{\prime} w^{\prime}$ 'he filled it' \\
\hline & & u-chu-ku-wa, uchuku'w 'he caught him' \\
\hline & & u-TZUTZ-wa, $u t z u t z[u$ '] $w$ 'he finished it' \\
\hline \multirow[t]{2}{*}{$\begin{array}{l}\ldots-\mathbf{C o}-\mathbf{w a},-o^{\prime} w \text { or } \\
\mathrm{L}_{0}-\mathbf{w a},-\left[o^{\prime}\right] w\end{array}$} & 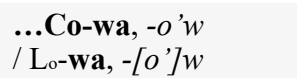 & $\begin{array}{l}\text { u-CHOK-wa, uchok[o]'w / u-CHOK-ko-wa / } \\
\text { u-cho-ko-wa, uchoko'w 'he scattered it' }\end{array}$ \\
\hline & & $\begin{array}{l}\text { u-ko-b'o-wa, } u k o b^{\prime} o^{\prime} w \text { 'he engendered it' (PAL, } \\
\text { Sarc., cf. MacLeod 2004) }\end{array}$ \\
\hline
\end{tabular}

Why is it the case that we consistently get the wa glyphic ending if roots in $i$ and $a$ should take a wu suffix? The answer to this question might simply be that the writing system does not have a wu syllabic sign. That would be the case if a sequen- 
ce of $/ \mathrm{w} /$ and $/ \mathrm{u} /$ were never found in Classic Ch'olan. This is not an unreasonable hypothesis since $-w u$ - is indeed a rare sequence in Ch'olan languages, as in Mayan languages in general. Some words which sometimes have the shape as $w u \ldots$ in some of the Ch'olan languages, turn out to be reconstructable as $h u$... A salient example is the numeral 'seven', reflected as Ch'ol wuk, Ch'olti' wuk, Ch'orti' uk reconstructed as *huk for proto-Ch'olan ( < proto-Mayan *huuq-uub' 'seven' ) by Kaufman and Norman (1984: 138, \#669). It is notable that Kaufman and Norman (1984) have no reconstructions in $*_{w u} .$. We believe quite firmly that the Maya could not have invented a wu syllable for the mere purpose of using it in complementation. Indeed, the reason why no wu syllabic sign has so far been deciphered may well be that there is no such sign in the system. The sign wa could then have been used as a default sign, a place-holder in a situation where there was no way to satisfy the requirements of the writing system.

A second possibility has recently been suggested by MacLeod (2004). This is the possibility that wa simply indicates as short - aw ending, i.e. a suffix which is not vowel-harmonic. MacLeod (2004: 296-297) makes the following statement:

«Kaufman (1989 and personal communication, 2000) has reconstructed plain-status root-transitive *-a(w) for Western Mayan, with reflexes *[-a] in Greater Tzeltalan and partially assimilative *-aw in Greater Q'anjob'alan. His assumptions are also supported by root-transitive imperatives in these languages in which the suffix is invariably

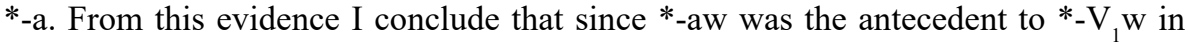
proto-Ch'olan, the wa suffix may be an archaic synharmonic spelling».

MacLeod seems to be arguing that during Classic times the affix in question acquired the shape $-\mathrm{V}_{1} \mathrm{w}$, but that it started out as $-a w$ and retained that shape long enough for -wa spellings to become ingrained in the script. The assumption of a vowel-harmonic $-\mathrm{V}_{1}$ w suffix intermediate between the Early Classic and the modern period may be supported by citing evidence from Ch'ol, where there is generally full vowel harmony in the cognate suffix $-\mathrm{V}_{1}^{8}$, as well as from Ch'olti', where it is generally the case that CVC transitives take a vowel-harmonic $-\mathrm{V}_{1}$ suffix (e.g., $b$ 'oj-o 'barrenar, clavar', juch'-u 'amasar', pech-e 'apretar con las manos, hacer tortillas, cf. Morán 1695 via Sattler 2004; Section 2.2, who cites Morán in a normalized orthography). Some other CVC transitives in Ch'olti', several of them recognizable as derivatives, take a variety of non-vowel harmonic suffixes. In modern Ch'orti' the verbs that previously took a vowel-harmonic suffix now take $-i$ and vowel harmony only remains when the root vowel is $e$ (cf. Wichmann 1999: Section 2.2). Both Colonial and Modern Chontal have replaced the vowel-harmonic suffix with $-i$ for all transitives (Bricker 1986: 126, Table 25).

In the end the resolution to the problem of choosing between the transliterations $-w a$ and $-V_{\mathrm{i}}$ 'w will probably have to come from historical linguistics. Currently the evidence weighs in favor of - $a w$. Nevertheless, we should be open to the possibility that it was - $V_{1}$ 'w since it seems a bit strange that there should be a non-vowel harmonic suffix that turned vowel-harmonic during the Classic and then stopped being vowel-harmonic in Chontal and generally also in Ch'orti' later on. The glottal is not

\footnotetext{
8 More precisely, the suffix behaves as follows: «Los radicales verbales con la estructura silábica CVC presentan una vocal final igual a la de la raíz, con la excepción de que la vocal adicional es a si la vocal de la raíz es $a$. En Tumbalá la vocal adicional después de $a$ en la raíz es $a$ si la raíz termina en $j$ y a si la raíz termina en otra consonante» (Warkentin and Scott 1980: 34).
} 
straightforwardly reconstructable, but we do note that Chontal has a glottal in its corresponding morpheme $-e$ '. This suffix could have developed from $-V_{1}$ ' $\mathrm{w}$ by a replacement of the harmonic vowel with $e$ and by a loss of the $w$. Even if a glottal stop in the thematic suffix is not reconstructed for proto-Mayan there is still a possibility that it could have been present in proto-Ch'olan as an innovation in this group. The proto-Mayan root transitive plain/declarative and the dependent/optative status suffixes have been reconstructed as respectively *-aw and *-a'. In Chuj the root transitive dependent/optative status marker has influenced the plain/declarative status marker such that the latter presents a glottalized form (see Kaufman 1986: 228; Robertson 1992: 167). In light of the glyphic evidence we consider it possible that a similar analogical process took place in Ch'olan, giving rise to $-V_{1}^{\prime} \mathrm{W}$ from earlier $-V_{1} \mathrm{w}$. Whatever the solution to the reconstruction problem is, it is important to point out there there is no reason whatsoever to posit a morphosyllable -AW.

\section{5. -oom 'Nominal Suffix' vs. -o'm 'Agentive Nominal Suffix'}

Across the Mayan languages there is variation in the shape of the word for 'head', with K'ichean languages reflecting a form reconstructable as *joloom and the Lowland Languages having *jó'ol (Yucatecan) or *jol (Ch'olan, Tzeltalan). The Greater Q'anjob'alan languages Q'anjob'al, Akateko, and Chuj reflect the suffixed form *jolom. Thus, the suffixed form is generally the more widespread, occurring in both the Eastern and Western branches of the language family. It appears that the inscriptions, at least in some cases, preserve the suffixed form. An example is the royal name from Yaxchilan CHAK-JOL-mi (read as such by Martin and Grube 2000, in replacement of the former reading CHAK-CHAM-mi). Our rules allow for the following possibilities of interpreting the suffix: either as -im, eem, -aam, -uum or -oom. Given the presence of *joloom 'head' and the absence of any form in the extant languages that would correspond to the other possibilities the interpretation joloom seems straightforward. The interesting thing about inscriptional JOL-mi is that it provides a contrast to the agentive expressions of the shape LOGOGRAMma or ...-Co-ma. The latter are unambiguous with regard to the shape of the suffix, which should be $-o$ ' $m$ under our interpretation of the spelling rules. Some examples are:

Derivation from a noun:

ka-yo-ma, kay-o'm 'fisherman'

Derivations from intransitive verbs:

k'a-yo-ma, $k$ 'ay-o'm 'singer'

ko-ko-ma, koko'm (a name)

cho-lo-ma sa-ja-la, cholo'm sajal 'liner-up of sajals (?)' (K3199, K4378)

SIHOM-ma, siho'm (part of month name expressions)

ta-jo-ma u-K'AB' K'AK' 'splitter of the blazes' (a name phrase at Calakmul identified by Nikolai Grube)

Derivations from transitive verbs:

ko-ko-no-ma, $k o[h] k-n-o$ 'm 'caretaker' (Copan, T.11)

a-AK'-no-ma, $a k$ '-n-o'm 'giver'

yu-ku-no-ma, $y u k-n-o$ 'm 'joiner' 
The three last forms show that the agentives are built on intransitives, requiring transitives to undergo prior antipassivization before receiving the $-o$ ' $m$ suffix. The antipassivization suffix is -oon, but gets syncopated to $-n$ when $-o$ ' $m$ is added, attracting the word stress according to the general rule of syllable-final stress.

The agentive suffix has been reconstructed as $*_{-O}-$ om for root transitives and *-om for derived transitives (Kaufman 1986: 111). These are underlying forms. It is not clear whether the product would be $*_{o}$ ' or *oo in the form *-o-om. Obviously we would prefer $-o$ ' $m$. Teko has the form aalo' $m$ 'animal', which could contain a reflex of the suffix under consideration, and there is a reconstructed Western Mayan -e-'m 'agent noun' suffix (Kaufman 1986: 201) that could have provoked analogy. Furthermore, the agentive suffix fails to turn up as -um in Ch'olan, as we might expect if *-oom was the correct reconstruction. As is so often the case, the historical linguistic data do not provide hard and ready evidence for the shape of the suffix. We have to be contend to note that a reconstruction $-o$ ' $m$ is not improbable. But the point here is not so much to appeal to the external evidence for confirmation of the hypothesis, but rather to strenghten it by internal evidence. We note that there is a clear distinction in the script between a suffix whose spelling involves the syllabic sign mi and one whose spelling involves ma signs. We also note that the most plausible candidate for both suffixes involves an $o$ vowel. If the Maya scribes did not intend some distinction other than the quality of the vowel of the suffix, why would they use signs that do not signal the correct quality? To us, spellings such as these provide prima facie evidence for the extension of the harmony rules to the suffix domain.

\section{6. -aj 'Nominalizer' vs. -aaj 'Perfect Participle of CVC-Roots'}

As mentioned in Lacadena (2004: 178, note 104) there is an -aj nominalizing suffix which occurs in the name of the Copan ruler Yax Pasaj Chan Yop At, for instance. Here pa-sa-ja spells pasaj 'opening' and the whole name may be translated as 'Yop At Is the First Opening (Dawn) in the Sky'. The suffix is also found in the expression u-te-k'a-ja 'it is his stepping' on a limestone panel from Palenque showing Kan B'ahlam in the act of dancing. The Classic Ch'olan nominalizing suffix is cognate with Chontal and Ch'ol $-a$ and Ch'orti' $-a j$. Since the $a: \ddot{a}$ is neutralized before $j$ in Western Ch'olan the fact that the quality of the vowel is $a$ does not tell us whether the vowel was short or long in the earlier times. The nominalizing suffix is homophonous with the - aj inchoative (attested in AJAW-ja 'he became a ruler'), the $-a j$ absolutive of a certain class of nouns (Stuart et al. 1999; Zender 2004), and the $-a j$ thematic suffix on derived intransitives. Each of these forms a minimal pair with the -aaj 'perfect participle of CVC-roots' attested in the expression u-na-wa-ji 'he has adorned it' (Palenque, Temple of the Inscriptions).

\section{Overview}

The minimal pairs (or triplets) that we have been discussing illustrate the $\mathrm{V}: \mathrm{VV}$ : V'(V) three-way contrast among suffixes in the Mayan script. The instances of contrasts that were specifically illustrated are: 

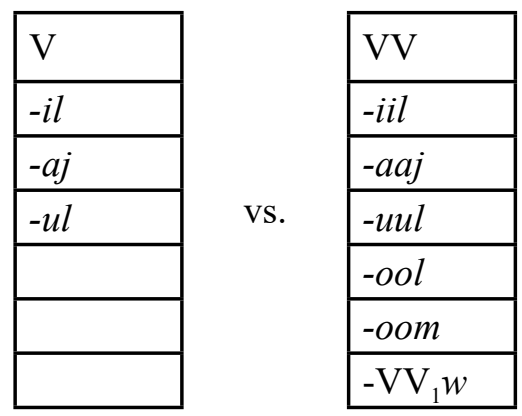

\begin{tabular}{|l|}
\hline $\mathrm{V}^{\prime}(\mathrm{V})$ \\
\hline \\
\hline$-u^{\prime} u l$ \\
\hline$-o^{\prime} l$ \\
\hline$-o^{\prime} m$ \\
\hline$-\mathrm{V}_{1}^{\prime} w$ \\
\hline
\end{tabular}

Our hypothesis is that the systematic differences in spellings serve to represent the phonological contrasts indicated. Any alternative hypothesis regarding the orthographic conventions would need to explain in some other way why the differences are there and why they are systematic in the sense that a particular suffix is always treated in the same way with respect to harmony patterns (except when affected by a sound change).

The suffixes we have been looked at do not make up the only minimal pairs to be found and they of course represent only a small subset of the suffixes attested so far in the inscriptions. Tables 3-4 give an overview of the Ch'olan suffixes identified to date in the inscriptions (thus excluding those that uniquely relate to Yucatecan). These tables are intended to provide materials for future work comparing the hieroglyphic evidence with reconstructions and for showing that the phonological shapes of the suffixes as we interpret them are distributed broadly over the various possible general suffix shapes. The typical shape of a Classic Ch'olan suffix is vowel-initial and consonant-final. Suffixes of the shape $-\mathrm{C}$ are probably derived historically from suffixes of the typical shape that have lost their vowels by syncopation because they would be followed by other suffixes. Suffixes in both initial consonant and final consonants probably derive from either strings of two vowel-consonant suffixes or from grammaticalized lexical morphemes.

\section{Conclusion}

In this paper we have presented a series of arguments for the following hypothesis: the harmony rules proposed in our 2004 paper, which represents a modest revision of Houston et al. (1998, 2004), apply not only to the lexical domain, but also to the domain of suffixes. Maya scribes did not make any distinction in their orthographic principles when they wrote a word containing a suffix and a word not containing a suffix. For instance, for 'bean' they wrote b'u-la. Here they chose the la sign rather than some other IV sign because the word for 'bean', b'u'ul, contains a glottal stop. Similarly the place name ma-su-la was written with a la sign because the end of the word was pronounced ...u'ul, just like the end of the word for 'bean'. The two words rhyme, and the ways they are written are 'in tune'. Are our proposals 'in tune' with the actual facts? That we can never know. We can only approach the problems of interpretation by applying a detached, scientific procedure. The basic requirement is not that we satisfy whatever initial intuitions we might have, but rather the following: we should choose the explanation which in a maximally simple and econo- 
Table 3. Vowel-initial suffixes in Classic Ch'olan

\begin{tabular}{|c|c|c|c|c|}
\hline & $-V$ & $-V(h) C$ & $-V V(h) C$ & $-V^{\prime}(V)(h) C$ \\
\hline $\mathrm{i}$ & $\begin{array}{l}-i \text { 'thematic of } \\
\text { CVC-intransi- } \\
\text { tives' }\end{array}$ & $\begin{array}{l}-i b \text { ' 'instrumental' } \\
-i j \text { 'perfective of } \\
\text { derived transitives' } \\
-i j \text { 'suffix on time } \\
\text { periods' } \\
-i k \text { 'optative' } \\
-i l \text { 'inalienable } \\
\text { possession' } \\
-i l \text { 'abstractivizer' } \\
-i s \text { 'absolutive' }\end{array}$ & $\begin{array}{l}\text {-iij ( }-a j) \text { 'denominalizer' } \\
\text {-iil 'toponymic' } \\
\text {-iiy 'temporal deixis' }\end{array}$ & \\
\hline e & & $\begin{array}{l}\text {-el 'absolutive of } \\
\text { body-parts' }\end{array}$ & & $\begin{array}{l}-e ' l \text { 'nominalizer of intransitive } \\
\text { verbs' } \\
-e^{\prime} m \text { 'agent noun' (?) } \\
-e ' n \text { 'first person absolutive' }\end{array}$ \\
\hline $\mathrm{a}$ & $\begin{array}{l}-a \text { 'verbalizer } \\
\text { (transitivizer)' } \\
-a \text { 'person } \\
\text { from' }\end{array}$ & $\begin{array}{l}-a j \text { 'absolutive' } \\
-a j \text { 'inchoative' } \\
-a j \text { 'nominalizer' } \\
-a j(\text { ( / - } i i j) \text { 'denomi- } \\
\text { nalizer' } \\
\text {-al 'nominalizer' }\end{array}$ & $\begin{array}{l}\text { - } a a b \text { ' 'instrumental' } \\
\text { - } a a l \text { 'abstractive' }\end{array}$ & \\
\hline $\mathrm{u}$ & & & $-u u b$ ' 'instrumental' & -u'ul 'toponymic' \\
\hline o & & & -oon 'antipassive' & $\begin{array}{l}-o ' b \text { ' 'third person plural absolu- } \\
\text { tive' } \\
-o \text { 'l 'nominalizer of transitives' } \\
-o \text { 'm 'agentive' } \\
-o \text { 'm 'future participial' } \\
-o \text { 'n 'first person plural absolutive' }\end{array}$ \\
\hline $\mathrm{V}_{1}$ & & $\begin{array}{l}\text {-Vich 'adjectivizer' } \\
\text {-V } \mathrm{V}_{1} \text { ' 'attributizer' }\end{array}$ & $\begin{array}{l}-V_{1 j} \text { 'perfect of transitives' } \\
-V_{1} l \text { 'participial of transitives' } \\
\text {-VV } 1 \text { 'stative of positionals' } \\
\text {-VViw 'antipassive' } \\
\text {-VViy 'mediopassive' }\end{array}$ & $\begin{array}{l}\text {-Vi' }[h] t \text { 'nominal derivational } \\
\text { suffix' } \\
\text {-V1'w 'thematic of CVC transiti- } \\
\text { ves' }\end{array}$ \\
\hline
\end{tabular}

Table 4. Consonant-initial suffixes in Classic Ch'olan

\begin{tabular}{|c|c|c|c|c|c|}
\hline & $-\mathrm{C}$ & $-\mathrm{CV}$ & $-\mathrm{CVC}(\mathrm{V}(\mathrm{h}) \mathrm{C})$ & $-\operatorname{CVV}(h) C$ & $-C^{\prime}(h) C$ \\
\hline $\mathrm{i}$ & & & $\begin{array}{l}\text {-l-ib' 'instrumental of } \\
\text { positional' }\left(<V_{l} l-i b \text { ') }\right. \\
\text {-pik 'classifier' } \\
\text {-tikil 'classifier (people)' }\end{array}$ & & \\
\hline $\mathrm{e}$ & & & $\begin{array}{l}\text {-lel 'abstractivizer' }(<-e l-e l \\
\text { or -il-el or -il-ill) } \\
\text {-te, 'classifier for upright } \\
\text { objects (stones, mountains)' }\end{array}$ & & \\
\hline $\mathrm{a}$ & & $\begin{array}{l}-y a \text { 'nominalizer } \\
\text { (deverbalizer)' }\end{array}$ & $\begin{array}{l}\text {-laj 'completive of intransi- } \\
\text { tive positional' } \\
\text {-lat 'later' } \\
\text {-nahb' 'classifier' } \\
\text {-nal 'place of, abundance } \\
\text { of' } \\
\text {-nal 'dweller, person from' } \\
\text {-tzak 'classifier' } \\
\text {-tz'ak 'classifier' } \\
\text {-tal 'classifier' }\end{array}$ & $\begin{array}{l}\text {-taak 'plural mar- } \\
\text { ker (animate)' } \\
\text {-taal 'incompleti- } \\
\text { ve of intransitive } \\
\text { positional' } \\
\text {-waan 'completi- } \\
\text { ve of intransitive } \\
\text { positional' }\end{array}$ & \\
\hline \multicolumn{6}{|l|}{$\mathrm{u}$} \\
\hline \multicolumn{6}{|l|}{ o } \\
\hline$\varnothing / \mathrm{V}_{1}$ & $\begin{array}{l}\text {-n 'passivizer of non- } \\
\text { CVC transitives' } \\
\text {-w 'passivizer of non- } \\
\text { CVC transitives' } \\
\text {-p 'mediopassive' (?) }\end{array}$ & $\begin{array}{l}-b \text { ' } a /-b \text { ' } u \text { 'transiti- } \\
\text { vizer of positionals' }\end{array}$ & & & \\
\hline
\end{tabular}


mical way accounts for the facts observed, and we should prefer an account which makes explicit and precise predictions such that it is potentially open to falsification. It should be clear by now that we make very strong and precise predictions concerning the phonological shapes of the suffixes attested in the script. Often these shapes conform nicely to historical linguistic reconstructions. In a few cases there may be discrepancies. This is exactly as it should be. Historical linguists have only just begun to incorporate observations regarding the language(s) of the Mayan hieroglyphic inscriptions into the larger history of the Mayan languages. The time is now ripe for historical linguists to reap the full harvest of epigraphic discoveries for the benefit of Mayan historical linguistics.

PostsCRIPT AND ACKNOWLEDGEMENTS: This paper was written during 2001-2004. In 2004 we submitted it to Research Reports on Ancient Maya Writing, but it was apparently never reviewed. So the paper has remaining unpublished to this day although it has circulated online since 2004. Apart from this little note, the manuscript, which represents the last major collaborative effort of its two authors, is presented here in its original form. During the time of writing SW's research was mainly funded by the Danish Institute for Advanced Studies in the Humanities, the Carlsberg Foundation and the Max-Planck-Gesellschaft; current sources of funding include a subsidy of the Russian Government to support the Programme of Competitive Development of Kazan Federal University. First and foremost, however, the present writer would like to extend his gratitude to Alfonso Lacadena for years of very productive collaboration - mainly during 1997-2004 — and for a warm and lasting friendship.

\section{References}

Ajpacaja Tum, Pedro Florentino, Manuel Isidro Chox Tum and Francisco Lucas Tepaz Raxuleu. 1996. Diccionario del idioma k'iche'. Antigua Guatemala: Proyecto Lingüístico Francisco Marroquín.

Andrés, Domingo, Karen Dakin, José Juan, Leandro López and Fernando Peñalosa. 1996. Diccionario akateko-español. Rancho Palos Verdes: Ediciones Yax Te'. Proyecto Lingüístico Francisco Marroquín.

Aulie, H. Wilbur and Evelyn W. de Aulie. 1978. Diccionario ch'ol-español, español-ch'ol. Serie de Vocabularios y Diccionarios Indígenas Mariano Silva y Aceves 21. Mexico: Instituto Lingüístico de Verano.

Barrera Vásquez, Alfredo, ed. 1995. Diccionario maya. Maya-español, español-maya, 3a edición. Mexico: Editorial Porrúa.

Bricker, Victoria. 1986. A Grammar of Mayan Hieroglyphs. Middle American Research Institute 56. New Orleans: Tulane University.

Bricker, Victoria, Eleuterio Po'Ot Yah and Ofelia Dzul de Po'Ot. 1998. A Dictionary of the Maya Language as Spoken in Hocabá, Yucatán. Salt Lake City: The University of Utah Press.

Canger, Una. 1970. Lacandón de San Quintín Vocabulary, Compiled 1969-70 by Una Canger. Computerized manuscript in possession of the authors.

Diego Antonio, Diego de, Francisco Pascual, Nicolas de Nicolas Pedro, Camelino Fernando Gonzales and Santiago Juan Matías. 1996. Diccionario del idioma q'anjob'al. Antigua Guatemala: Proyecto Lingüístico Francisco Marroquín.

Grube, Nikolai. 2004. «The Orthographic Distinction Between Velar and Glottal Spirants in Maya Hieroglyphic Writing», in The Linguistics of Maya Writing, Søren Wichmann, ed., pp. 61-81. Salt Lake City: The University of Utah Press. 
Hofling, Charles A. and Félix F. Tesucún. 1997. Itzaj Maya - Spanish - English Dictionary. Diccionario maya itzaj-español-inglés. Salt Lake City: The University of Utah Press.

Houston, Stephen D. 1993. Hieroglyphs and History at Dos Pilas. Austin: University of Texas Press.

Houston, Stephen, John Robertson and David Stuart. 2001. Quality and Quantity in Glyphic Nouns and Adjectives. Research Reports on Ancient Maya Writing 47. Washington, D.C.: Center for Maya Research.

Houston, Stephen, David Stuart and John Robertson. 1998. «Disharmony in Maya Hieroglyphic Writing: Linguistic Change and Continuity in Classic Society», in Anatomía de una civilización. Aproximaciones interdisciplinarias a la cultura maya, Andrés Ciudad, Yolanda Fernández, José Miguel García, Ma Josefa Iglesias, Alfonso Lacadena y Luis T. Sanz, eds., pp. 275-296. Madrid: Sociedad Española de Estudios Mayas.

- 2004. «Disharmony in Maya Hieroglyphic Writing: Linguistic Change and Continuity in Classic Society», in The Linguistics of Maya Writing, Søren Wichmann, ed., pp. 83-101. Salt Lake City: The University of Utah Press.

Jackson, Sarah and David Stuart. 2001. «The Aj K'uhun Title: Deciphering a Classic Maya Term of Rank». Ancient Mesoamerica 12 (2): 217-228.

Kaufman, Terrence S. 1986. Outline of Comparative Mayan Grammar. I: Morphology and Particles. With William Norman. Pittsburgh. Manuscript in possession of the authors.

Kaufman, Terrence S. and William M. Norman. 1984. «An Outline of Proto-Cholan Phonology, Morphology and Vocabulary», in Phoneticism in Mayan Hieroglyphic Writing, John Justeson and Lyle Campbell, eds., pp. 77-166. Institute of Mesoamerican Studies 9. Albany: State University of New York at Albany.

Keller, Kathryn C. and Plácido Luciano G. 1997. Diccionario chontal de Tabasco. Tucson: Summer Institute of Linguistics.

Lacadena, Alfonso. 1997. «Bilingüismo en el Códice de Madrid», in Los investigadores de la cultura maya 5, pp. 84-204. Campeche: Universidad Autónoma de Campeche and Secretaría de Educación Pública.

. 2004. «Passive Voice in Classic Mayan Texts», in The Linguistics of Maya Writing, Søren Wichmann, ed., pp. 165-194. Salt Lake City: The University of Utah Press.

Lacadena, Alfonso and Søren Wichmann. 2002. «The Distribution of Lowland Maya Languages in the Classic Period», in La organización social entre los mayas. Memoria de la Tercera Mesa Redonda de Palenque, Vol. II, Vera Tiesler, Rafael Cobos and Merle Greene Robertson, eds., pp. 275-314. Mexico: Instituto Nacional de Antropología e Historia and Universidad Autónoma de Yucatán.

- 2004. «On the Representation of the Glottal Stop in Maya Writing», in The Linguistics of Maya Writing, Søren Wichmann, ed., pp. 103-162. Salt Lake City: The University of Utah Press.

Lenkersdorf, Carlos. 1979. B'omak'umal tojol ab'al-kastiya; Diccionario tojolabal-español: idioma mayance de los Altos de Chiapas. Mexico: Editorial Nuestro Tiempo.

MacLeod, Barbara. 2004. «A World in a Grain of Sand: Transitive Perfect Verbs in the Classic Maya Script», in The Linguistics of Maya Writing, Søren Wichmann, ed., pp. 291325. Salt Lake City: University of Utah Press.

Martin, Simon and Nikolai Grube. 2000. Chronicle of the Maya Kings and Queens. Deciphering the Dynasties of the Ancient Maya. London: Thames and Hudson.

Mayer, Karl H. 1989. Sculptures of Unknown Provenance (V). Berlin: Verlag Van Flemming. 
Morán, Fray Francisco de. 1695. Arte y Vocabulario de la lengua Cholti que quiere decir la Lengua de Milperos. Manuscript Collection 497.4/M79. Philadelphia: American Philosophical Society.

Robertson, John S. 1992. The History of Tense / Aspect / Mood / Voice in the Mayan Verbal Complex. Austin: University of Texas Press.

Roys, Ralph L. 1967. The Book of Chilam Balam of Chumayel. Norman: University of Oklahoma Press.

Sattler, Mareike. 2004. «Ch'olti’: An Analysis of Arte de la lengua ch'olti' by Fray Francisco Morán», in The Linguistics of Maya Writing, Søren Wichmann, ed., pp. 365-405. Salt Lake City: The University of Utah Press.

Schele, Linda. 1991. Notebook for the XVth Maya Hieroglyphic Workshop at Texas. Austin: The University of Texas at Austin.

— 1993. Notebook for the XVIIth Maya Hieroglyphic Workshop, March 13-14, 1993. Austin: The University of Texas at Austin.

Stuart, David. 1987. Ten Phonetic Syllables. Research Reports on Ancient Maya Writing 14. Washington, D.C.: Center for Maya Research.

- 1998. «'The Fire Enters his House': Architecture and Ritual in Classic Maya Texts», in Function and Meaning in Classic Maya Architecture, Stephen D. Houston, ed., pp. 373-425. Washington, D.C.: Dumbarton Oaks.

. 2000. «Ritual and History in the Stucco Inscription from Temple XIX at Palenque». The PARI Journal 1 (1): 13-19.

Stuart, David, Stephen D. Houston and John Robertson. 1999. «Recovering the Past: Classic Maya Language and Classic Maya Gods», in Notebook for the XXIIIrd Maya Hieroglyphic Forum at Texas. Austin: Dept. Of Art and Art History, the College of Fine Arts, and the Institute of Latin American Studies, The University of Texas at Austin.

Thompson, J. Eric S. 1971 [1950]. Maya Hieroglyphic Writing: An Introduction. Norman: University of Oklahoma Press.

Ulrich, E. Mathew and Rosemary Dixon de Ulrich. 1976. Diccionario maya mopán-español, español-maya mopán. Guatemala: Instituto Lingüístico de Verano en Guatemala.

Warkentin, Viola and Ruby Scott. 1978. Gramática ch'ol. Serie de gramáticas de lenguas indígenas de México 3. Mexico: Instituto Lingüístico de Verano.

Wichmann, Søren. 1999. A Ch'orti' Morphological Sketch. Manuscript.

- 2004. «The Names of Some Major Classic Maya Gods», in Continuity and Change -Mayan Religious Practices in Temporal Perspective, Daniel Graña Behrens, Nikolai Grube, Christian M. Prager, Frauke Sachse, Stefanie Teufel and Elisabeth Wagner, eds., pp. 77-86. Acta Americana 14. Markt Schwaben: Verlag Anton Saurwein.

Wichmann, Søren and Cecil H. Brown. 2004. «Proto-Mayan Syllable Nuclei». International Journal of American Linguistics 70 (2): 128-186.

Wisdom, Charles. 1950. Materials on the Chorti Language. Microfilm Collection of Manuscript Materials on Middle American Cultural Anthropology 28. Chicago: University of Chicago Library.

Zender, Marc. 1999. Diacritical Marks and Underspelling in the Classic Maya Script: Implications for Decipherment. M.A. thesis, Dept. of Archaeology. Calgary: University of Calgary.

. 2004. «On the Morphology of Intimate Possession in Mayan Languages and Classic Mayan Glyphic Nouns», in The Linguistics of Maya Writing, Søren Wichmann, ed., pp. 195-209. Salt Lake City. The University of Utah Press. 
n.d. «The Toponyms of El Cayo, Piedras Negras and La Mar». Manuscript in possession of the authors.

Zipf, George K. 1949. Human Behavior and the Principle of Least-Effort. Cambridge: Addison-Wesley. 